\title{
Corrosion Inhibition of Carbon Steel in Well Water by L-Cysteine-Zn ${ }^{2+}$ System
}

\author{
J. A. Thangakani, ${ }^{a, *}$ S. Rajendran, ${ }^{b}$ J. Sathiabama, ${ }^{c}$ R. J. Rathish ${ }^{d}$ \\ and S. Santhanaprabha ${ }^{d}$ \\ ${ }^{a}$ C.E.O.A. Mat. Hr. Sec. School, Madurai - 625 017, Tamil Nadu, India \\ ${ }^{b}$ Department of Chemistry, RVS School of Engineering and Technology, \\ Dindigul - 624005 Tamil Nadu, India \\ ${ }^{c}$ Corrosion Research Centre, Department of Chemistry, GTN Arts College, \\ Dindigul - 624 005, Tamil Nadu, India \\ ${ }^{d}$ PSNA College of Engineering and Technology, Dindigul, Tamil Nadu, India
}

Received August 7, 2015; accepted October 30, 2016

\begin{abstract}
The environmental friendly inhibitor system L-cysteine- $\mathrm{Zn}^{2+}$ has been investigated by weight loss method. A synergistic effect exists between L-cysteine and $\mathrm{Zn}^{2+}$ system. The formulation consisting of $250 \mathrm{ppm}$ of L-cysteine and $50 \mathrm{ppm}$ of $\mathrm{Zn}^{2+}$ offers an excellent inhibition efficiency of $99 \%$. Polarization study reveals that this formulation functions as anodic inhibitor. AC impedance spectra reveal that a protective film is formed on the metal surface. FTIR spectra study leads to the conclusion that the $\mathrm{Fe}^{2+}$ L-cysteine complex formed on the anodic sites of the metal surface controlled the anodic reaction, and $\mathrm{Zn}(\mathrm{OH})_{2}$ formed on the cathodic sites of the metal surface controlled the cathodic reaction. A suitable mechanism of corrosion inhibition is proposed based on the results obtained from weight loss study and surface analysis technique. Synergism parameters have been calculated. They are found to be greater than 1, suggesting that a synergistic effect exists between L-cysteine and $\mathrm{Zn}^{2+}$.
\end{abstract}

Keywords: L-cysteine corrosion inhibitor, synergistic effect, carbon steel, well water, zinc ion, aminoacids.

\section{Introduction}

There has been a recent awareness about the health hazards of corrosion inhibition, and its best practices for health and safety. As hazardous chemicals have been restricted from contact with the environment, there has been an increasing look-out for non-toxic, eco-friendly corrosion inhibitors. Using inhibitors is one of the most pragmatic methods for protecting metals from corrosion.

\footnotetext{
*Corresponding author. E-mail address: angelinthangakani@gmail.com
} 
Corrosion inhibitor is a chemical which, when added to the corrodible surface in optimum concentration, significantly decreases the corrosion rate of metals (or) alloys. However, many common corrosion inhibitors are highly toxic and hazardous to health, such as chromates [1], nitrite [2] and aromatic heterocyclic compounds [3]. Hence, environmentally safe inhibitors [4-6] are much recommended. Researchers have investigated and found that amino acids are both effective and environmental-friendly metal corrosion inhibitors, [6-13]. This is because aminoacids are non-toxic, biodegradable, economical and completely soluble in aqueous media, and produced with high purity at low cost. L-cysteine was selected as environmental-friendly corrosion inhibitor for the present project. The document presents some studies about the capability of amino acids to prevent corrosion in iron [14], steel [15-17], aluminium [18, 19], nickel [20] and copper [21-25]. Polarization and AC impedance spectra [26-30] and cyclic voltametry [19] have been studied by using amino acids. The adsorption of amino acids on carbon steel in an acidic environment has been researched by Adiyama et al. [31].

The aim of the present study is:

1. To assess the inhibition efficiency of L-cysteine in controlling the corrosion of carbon steel in the absence and presence of $\mathrm{Zn}^{2+}$.

2. To evaluate the protective film on carbon steel by FTIR spectrophotometry.

3. To study the mechanistic aspects by AC impedance and potentiodynamic polarization studies.

4. To propose a suitable mechanism for corrosion inhibition based on the results from the above study.

\section{Experimental procedure}

\section{Preparation of specimens}

Carbon steel specimens $(0.0267 \% \mathrm{~S}, 0.067 \% \mathrm{P}, 0.4 \% \mathrm{Mn}, 0.1 \% \mathrm{C}$ and iron), with the dimensions $1.0 \mathrm{~cm} \times 4.0 \mathrm{~cm} \times 0.2 \mathrm{~cm}$, were polished to mirror finish, degreased with trichloroethylene, and used for weight loss method and surface examination studies.

\section{Weight loss method}

Carbon steel specimens, in triplicate, were immersed in $100 \mathrm{~mL}$ of well water and various concentrations of L-cysteine in the presence and absence of $\mathrm{Zn}^{2+}$ (as $\mathrm{ZnSO}_{4}, 7 \mathrm{H}_{2} \mathrm{O}$ ) for a period of seven days. The corrosion products were cleaned with Clarke's solution [32]. The weight of the specimens before and after immersion was determined using a Shimadzu balance AY62. The corrosion inhibition efficiency was calculated with equation (1).

$$
\mathrm{IE}=100\left[1-\left(\mathrm{W}_{2} / \mathrm{W}_{1}\right)\right] \%
$$

where $\mathrm{W}_{1}$ is the corrosion rate in the absence of the inhibitor, and $\mathrm{W}_{2}$ is the corrosion rate in the presence of an inhibitor. 


\section{Potentiodynamic polarization study}

Potentiostatic polarization studies were carried out using a $\mathrm{CHI}$ electrochemical impedance analyzer, model 660 A. A three-electrode cell assembly was used. The working electrode was a rectangular specimen of carbon steel with one face of the electrode $\left(1 \mathrm{~cm}^{2}\right.$ area) exposed, and the rest shielded with red lacquer. A saturated calomel electrode (SCE) was used as reference electrode, and a rectangular platinum foil was used as counter electrode. Polarization curves were recorded using IR compensation. The results, such as Tafel slopes, and Icorr, $\mathrm{E}_{\mathrm{corr}}$ and LPR values were calculated. During the polarization study, the scan rate (v/s) was 0.01 ; hold time at Ef(s) was zero and quit time(s) was 2.

\section{AC impedance measurements}

A CHI electrochemical impedance analyzer (model 660A) was used for AC impedance measurements. A time interval of 5 to 10 minutes was given for the system to attain its open circuit potential. The real part Z' and imaginary part Z" of the cell impedance were measured in ohms at various frequencies. Charge transfer resistance $R_{1}$, double layer capacitance $C_{d l}$ and impedance values were calculated.

where $\mathrm{R}_{\mathrm{s}}=$ solution resistance

$$
\mathrm{R}_{\mathrm{t}}=\left(\mathrm{R}_{\mathrm{s}}+\mathrm{R}_{\mathrm{t}}\right)-\mathrm{R}_{\mathrm{s}}
$$

$$
\mathrm{C}_{\mathrm{dl}}=1 / 2 \pi \mathrm{R}_{\mathrm{t}} \mathrm{f}_{\max }
$$

where $f_{\max }=$ maximum frequency

AC impedance spectra were recorded with initial $\mathrm{E}(\mathrm{v})=0$; high frequency $(\mathrm{Hz})=1 ; \operatorname{amplitude}(\mathrm{v})=0.05 ;$ and quiet time $(\mathrm{s})=2$.

\section{FTIR spectra}

The structure of L-cysteine is shown in Fig. 1. The carbon steel specimens immersed in various test solutions for one day were taken out and dried. The film formed on the metal surface was carefully removed and thoroughly mixed with $\mathrm{KBr}$, so as to make it throughout uniform. The FTIR spectra were recorded in a Perkin-Elmer 1600 spectrophotometer.

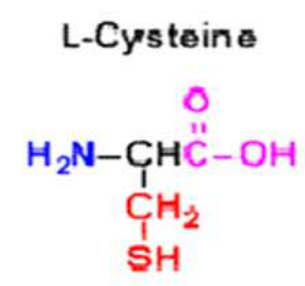

Figure 1. Structure of L-cysteine.

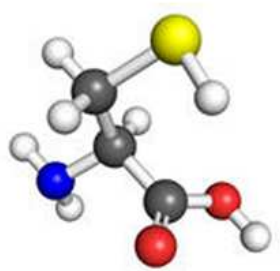

Ball and stick model of L-cysteine.

\section{Results and discussion \\ Analysis of results of the weight loss method}

Inhibition efficiencies (IE\%) of L-cysteine- $\mathrm{Zn}^{2+}$ systems in controlling corrosion of carbon steel immersed in well water, in the presence and absence of an inhibitor system (immersion period $=7$ days), are given in Tables 1 to 3 and Schemes 1 to 3 . 
Table 1. Corrosion rates (CR) of carbon steel immersed in well water, in the presence and absence of an inhibitor system at various concentrations, and inhibition efficiencies (IE) obtained by weight loss method.

\begin{tabular}{|c|c|c|c|}
\hline L-cysteine, $\mathbf{p p m}$ & $\mathbf{Z n}^{\mathbf{2 +}} \mathbf{p p m}$ & $\mathbf{C R}, \mathbf{m d d}$ & $\mathbf{I E \%}$ \\
\hline 0 & 0 & 282.70 & - \\
\hline 50 & 0 & 42.41 & 85 \\
\hline 100 & 0 & 33.92 & 88 \\
\hline 150 & 0 & 31.10 & 89 \\
\hline 200 & 0 & 25.44 & 91 \\
\hline 250 & 0 & 16.96 & 94 \\
\hline
\end{tabular}

Inhibitor system: L-cysteine- $\mathrm{Zn}^{2+}(0 \mathrm{ppm})$; immersion period: 7 days; $\mathbf{p H}: 3$

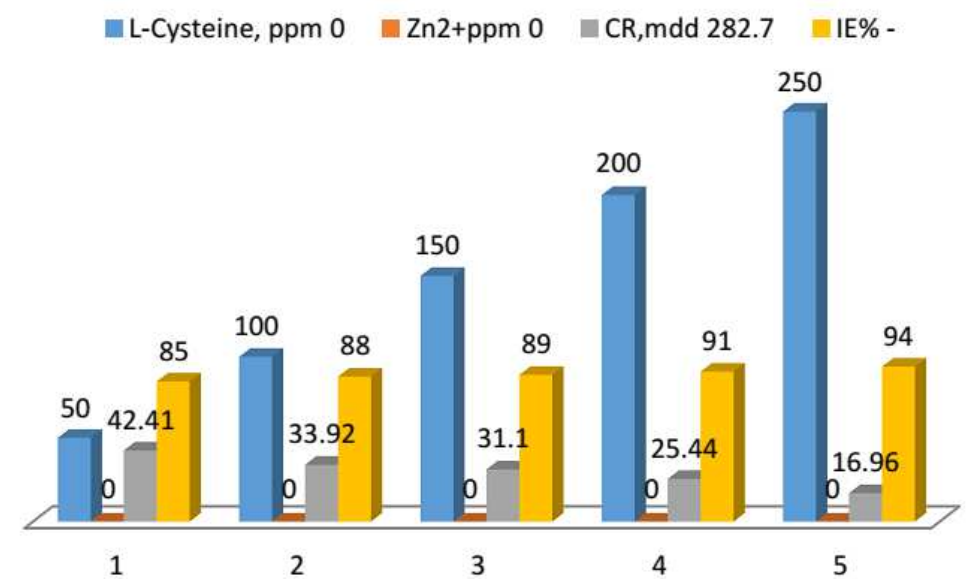

Scheme 1. Corrosion rates (CR) and (IE) of L-cysteine- $\mathrm{Zn}^{2+}(0 \mathrm{ppm})$.

Table 2. Corrosion rates (CR) of carbon steel immersed in well water, in the presence and absence of an inhibitor system at various concentrations, and inhibition efficiencies (IE) obtained by weight loss method.

\begin{tabular}{|c|c|c|c|}
\hline L-cysteine, $\mathbf{p p m}$ & $\mathbf{Z n}^{\mathbf{2 +}} \mathbf{p p m}$ & $\mathbf{C R}, \mathbf{m d d}$ & $\mathbf{I E \%}$ \\
\hline 0 & 0 & 282.70 & - \\
\hline 0 & 10 & 254.43 & 10 \\
\hline 50 & 10 & 28.27 & 90 \\
\hline 100 & 10 & 22.62 & 92 \\
\hline 150 & 10 & 19.79 & 93 \\
\hline 200 & 10 & 16.10 & 94 \\
\hline 250 & 10 & 14.14 & 95 \\
\hline
\end{tabular}

Inhibitor system: L-cysteine- $\mathrm{Zn}^{2+}(10 \mathrm{ppm})$; immersion period: 7 days; $\mathbf{p H}: 3$

It is observed that L-cysteine alone has poor inhibition efficiency. In the presence of various concentrations of $\mathrm{Zn}^{2+}(10$ and $50 \mathrm{ppm})$ the IE of L-cysteine increases. A synergistic effect exists between L-cysteine and $\mathrm{Zn}^{2+}$.

For example, $50 \mathrm{ppm}$ of L-cysteine has only $85 \% \mathrm{IE}$; $50 \mathrm{ppm}$ of $\mathrm{Zn}^{2+}$ has $15 \%$ IE. However, their combination has $92 \%$ IE. This suggests a synergistic effect between L-cysteine and $\mathrm{Zn}^{2+}$. 
L-Cysteine, ppm $0 \quad$ Zn2+ppm $0 \quad$ In, mdd $282.7 \quad$ IE\% -

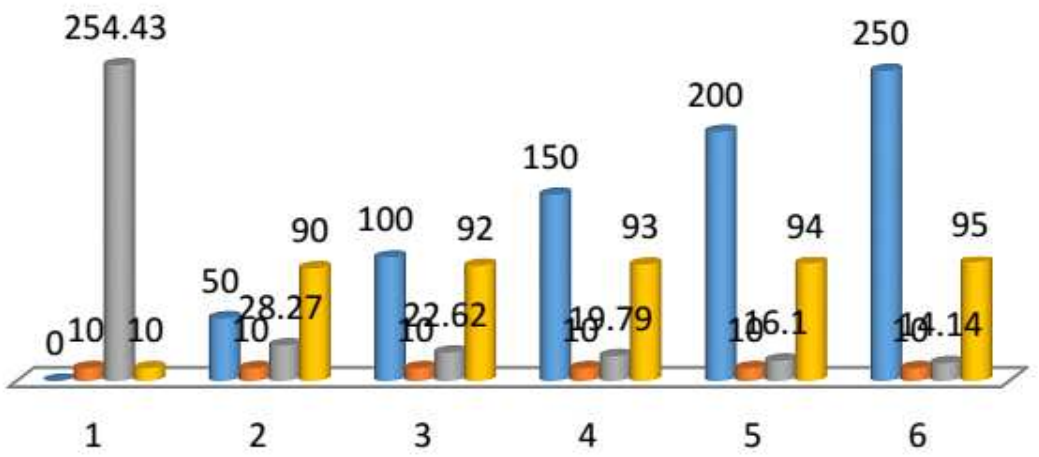

Scheme 2. Corrosion rates (CR) and (IE) of L-cysteine- $\mathrm{Zn}^{2+}(10 \mathrm{ppm})$.

Table 3. Corrosion rates (CR) of carbon steel immersed in well water, in the presence and absence of an inhibitor system at various concentrations, and inhibition efficiencies (IE) obtained by weight loss method.

\begin{tabular}{|c|c|c|c|}
\hline L-cysteine, $\mathbf{p p m}$ & $\mathbf{Z n}^{\mathbf{2}+} \mathbf{p p m}$ & CR, mdd & IE\% \\
\hline 0 & 0 & 282.70 & - \\
\hline 0 & 50 & 240.29 & 15 \\
\hline 50 & 50 & 22.62 & 92 \\
\hline 100 & 50 & 16.10 & 94 \\
\hline 150 & 50 & 11.31 & 96 \\
\hline 200 & 50 & 5.65 & 98 \\
\hline 250 & 50 & 2.83 & 99 \\
\hline
\end{tabular}

Inhibitor system: L-cysteine- $\mathrm{Zn}^{2+}(50 \mathrm{ppm})$; immersion period: 7 days; $\mathbf{p H}: 3$

- L-Cysteine, ppm $0 \quad \square$ Zn2+ppm $0 \quad \square$ CR, mdd $282.7 \quad \square \mathrm{IE} \%$ -

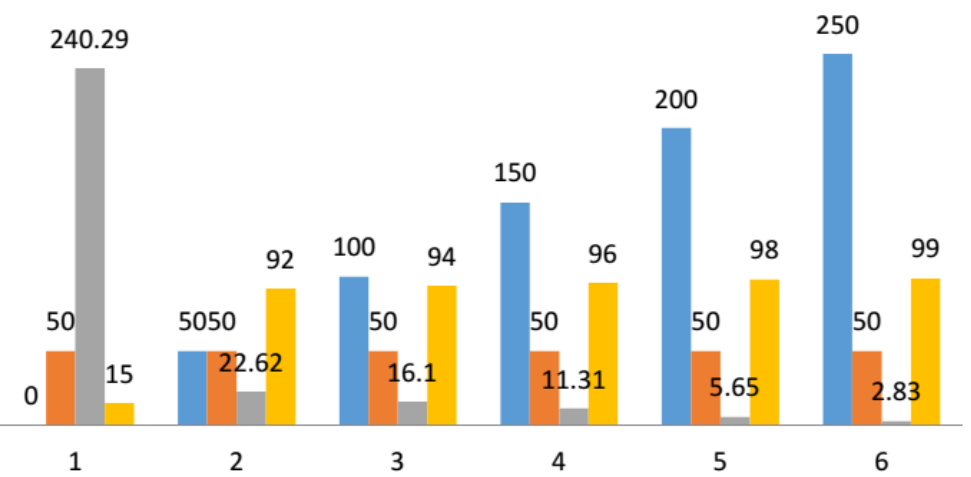

Scheme 3. Corrosion rates (CR) and (IE) of L-Cysteine- $\mathrm{Zn}^{2+}(50 \mathrm{ppm})$.

\section{Synergism parameter $\left(S_{I}\right)$}

Synergism parameter $\left(\mathrm{S}_{\mathrm{I}}\right)$ has been used to know the synergistic effect between two inhibitors [33 - 38]. Synergism parameter $\left(\mathrm{S}_{\mathrm{I}}\right)$ can be calculated as:

$$
S_{I}=\frac{1-\theta_{1+2}}{1-\theta^{\prime}{ }_{1+2}}
$$


where $\theta=$ surface coverage, $\theta_{1+2}=\left(\theta_{1}+\theta_{2}\right)-\left(\theta_{1} \theta_{2}\right), \theta_{1}=$ surface coverage by Lcysteine, $\theta_{2}=$ surface coverage by $\mathrm{Zn}^{2+}, \theta_{1+2}=$ surface coverage by both Lcysteine and $\mathrm{Zn}^{2+}$, and where

$$
\theta=\frac{\mathrm{IE} \%}{100}
$$

The synergism parameters of L-cysteine $-\mathrm{Zn}^{2+}$ system are given in Tables 4 and 5 . For different concentrations of inhibitors, $S_{\text {I }}$ approaches 1 when no interaction between the inhibitor and compounds exists. When $S_{I}>1$, it points to synergistic effects. If $S_{I}<1$, it is an indication that the synergistic effect is not significant. From Tables 4 and 5 , it is observed that values of synergism parameters $\left(\mathrm{S}_{\mathrm{I}}\right)$ calculated from the surface coverage were found to be one and above. This indicates that a synergistic effect exists between L-cysteine and $\mathrm{Zn}^{2+}[35,36,38]$. Thus, the enhancement of the inhibition efficiency caused by the addition of $\mathrm{Zn}^{2+}$ ions to L-cysteine is due to the synergistic effect.

Table 4. Inhibition efficiencies and synergism parameters for various concentrations of L-cysteine- $\mathrm{Zn}^{2+}(10 \mathrm{ppm})$ system.

\begin{tabular}{|l|c|c|c|c|c|c|c|c|}
\hline $\begin{array}{c}\text { L-cysteine, } \\
\mathbf{p p m}\end{array}$ & $\begin{array}{c}\text { Inhibition } \\
\text { efficiency, } \\
\text { IE \% }\end{array}$ & $\begin{array}{c}\text { Surface } \\
\text { coverage, } \\
\boldsymbol{\theta}_{\mathbf{1}}\end{array}$ & $\begin{array}{c}\mathbf{Z n}^{\mathbf{2 +}}, \\
\mathbf{p p m}\end{array}$ & $\mathbf{I E \%}$ & $\begin{array}{c}\text { Surface } \\
\text { coverage } \\
\boldsymbol{\theta}_{\mathbf{2}}\end{array}$ & $\begin{array}{c}\text { Combined } \\
\text { IE\% } \mathbf{I}_{\mathbf{1}+\mathbf{2}}\end{array}$ & $\begin{array}{c}\text { Combined } \\
\text { surface } \\
\text { coverage, } \\
\boldsymbol{\theta}_{\mathbf{1 + 2}}\end{array}$ & $\begin{array}{c}\text { Synergism } \\
\text { parameter, } \\
\text { SI }_{\mathbf{I}}\end{array}$ \\
\hline 50 & 85 & 0.85 & 10 & 10 & 0.10 & 90 & 0.90 & 1.35 \\
\hline 100 & 88 & 0.88 & 10 & 10 & 0.10 & 92 & 0.92 & 1.35 \\
\hline 150 & 89 & 0.89 & 10 & 10 & 0.10 & 93 & 0.93 & 1.41 \\
\hline 200 & 91 & 0.91 & 10 & 10 & 0.10 & 94 & 0.94 & 1.35 \\
\hline 250 & 94 & 0.94 & 10 & 10 & 0.10 & 95 & 0.95 & 1.08 \\
\hline
\end{tabular}

Table 5. Inhibition efficiencies and synergism parameters for various concentrations of L-cysteine- $\mathrm{Zn}^{2+}$ (50 ppm) system.

\begin{tabular}{|c|c|c|c|c|c|c|c|c|}
\hline $\begin{array}{c}\text { L-cysteine, } \\
\mathbf{p p m}\end{array}$ & $\begin{array}{c}\text { Inhibition } \\
\text { efficiency, } \\
\text { IE \% }\end{array}$ & $\begin{array}{c}\text { Surface } \\
\text { coverage, } \\
\boldsymbol{\theta}_{\mathbf{1}}\end{array}$ & $\begin{array}{c}\mathbf{Z n}^{\mathbf{2 +}} \mathbf{\mathbf { p p m }} \\
\mathbf{p p m}\end{array}$ & $\begin{array}{c}\text { IE } \\
\boldsymbol{\%}\end{array}$ & $\begin{array}{c}\text { Surface } \\
\text { coverage, } \\
\boldsymbol{\theta}_{\mathbf{2}}\end{array}$ & $\begin{array}{c}\text { combined } \\
\mathbf{I E}_{\mathbf{1 + 2}}\end{array}$ & $\begin{array}{c}\text { Combined } \\
\text { surface } \\
\text { coverage, } \\
\boldsymbol{\theta}_{\mathbf{1 + 2}}\end{array}$ & $\begin{array}{c}\text { Synergism } \\
\text { parameter, } \\
\mathbf{S}_{\mathbf{I}}\end{array}$ \\
\hline 50 & 85 & 0.85 & 50 & 15 & 0.15 & 92 & 0.92 & 1.59 \\
\hline 100 & 88 & 0.88 & 50 & 15 & 0.15 & 94 & 0.94 & 1.70 \\
\hline 150 & 89 & 0.89 & 50 & 15 & 0.15 & 96 & 0.96 & 2.34 \\
\hline 200 & 91 & 0.91 & 50 & 15 & 0.15 & 98 & 0.98 & 3.82 \\
\hline 250 & 94 & 0.94 & 50 & 15 & 0.15 & 99 & 0.99 & 5.10 \\
\hline
\end{tabular}

\section{Analysis of potentiodynamic polarization study $(\mathrm{pH}=3)$}

Polarization study has been used to confirm the formation of a protective film formed on the metal surface during corrosion inhibition process [39-44]. If a protective film is formed on the metal surface, the linear polarization resistance value (LPR) increases, and corrosion current value $\left(\mathrm{I}_{\text {corr }}\right)$ decreases. 
The potentiodynamic polarization curves of carbon steel immersed in well water, in the presence and absence of inhibitors, are shown in Fig. 2. The corrosion parameters are given in Table 6 . When carbon steel was immersed in well water, the corrosion potential was $-502 \mathrm{mV}$ vs. SCE. When L-cysteine $(250 \mathrm{ppm})$ and $\mathrm{Zn}^{2+}(50 \mathrm{ppm})$ were added to the above system, the corrosion potential shifted to the cathodic side $(-523 \mathrm{mV}$ vs. SCE). This indicates that the inhibitor system predominantly controls the cathodic reaction (formation of $\mathrm{OH}^{-}$). In the presence of the inhibitor system, the corrosion potential shifted from -502 to $-523 \mathrm{mV}$ vs. SCE. This shift is with $50 \mathrm{mV} /$ decade. Hence, it is concluded that the inhibitor system functions as a mixed type inhibitor system.

The anodic reaction $\left(\mathrm{Fe} \rightarrow \mathrm{Fe}^{2+}+2 \mathrm{e}^{-}\right)$is controlled by the formation of $\mathrm{Fe}^{2+}-$ inhibitor complex on the anodic sites of the metal surface.

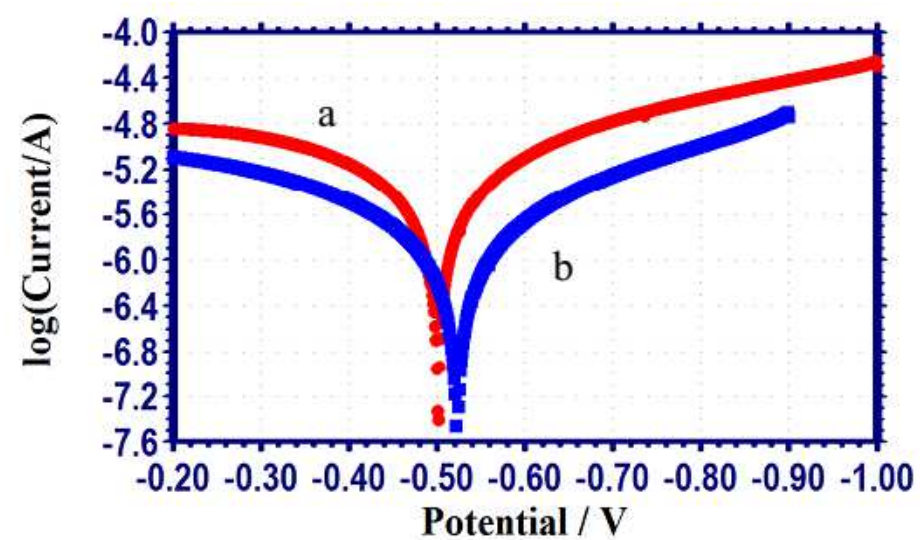

Figure 2. Polarization curves of carbon steel immersed in various test solutions. a) Well water. b) Well water + L-cysteine $(250 \mathrm{ppm})+\mathrm{Zn}^{2+}(50 \mathrm{ppm})$.

The cathodic reaction $\left(\mathrm{O}_{2}+2 \mathrm{H}_{2} \mathrm{O}+4 \mathrm{e}^{-} \rightarrow 4 \mathrm{OH}^{-}\right)$is controlled by the formation of zinc hydroxide $\left(\mathrm{Zn}^{2+}+2 \mathrm{OH}^{-} \rightarrow \mathrm{Zn}(\mathrm{OH})_{2} \downarrow\right)$ on the cathodic sites of the metal surface. Thus, both the anodic reaction for the generation of $\mathrm{Fe}^{2+}$, and the cathodic reaction for the formation of $\mathrm{OH}^{-}$are effectively controlled by the inhibitor system. This accounts for the mixed type of the inhibitor system and the synergistic effect between L-cysteine and $\mathrm{Zn}^{2+}$ system.

Further, the LPR value increased from $12948.8 \mathrm{ohm} \mathrm{cm}^{2}$ to $36560.5 \mathrm{ohm} \mathrm{cm}^{2}$; and the corrosion current decreased from $3.521 \times 10^{-6} \mathrm{~A} / \mathrm{cm}^{2}$ to $1.168 \times 10^{-6}$ $\mathrm{A} / \mathrm{cm}^{2}$. Thus, the polarization study confirms the formation of a protective film on the metal surface.

Table 6. Corrosion parameters of carbon steel immersed in well water in the absence of the inhibitor system obtained from potentiodynamic polarization study.

\begin{tabular}{|c|c|c|c|c|c|}
\hline System & $\begin{array}{l}\text { Ecorr } \mathbf{m V} \\
\text { vs. SCE }\end{array}$ & $\begin{array}{l}\text { bc, } \mathbf{m V} / \\
\text { decade }\end{array}$ & $\begin{array}{l}\text { ba, } \mathbf{m V} / \\
\text { decade }\end{array}$ & $\begin{array}{c}\text { Icorr, } \\
\mathbf{A} / \mathbf{c m}^{2} \\
\end{array}$ & $\begin{array}{c}\text { LPR, } \\
\text { ohm } \text { cm }^{2}\end{array}$ \\
\hline Well water & -502 & 0.1943 & 0.2276 & $3.521 \times 10^{-6}$ & 12948.8 \\
\hline $\begin{array}{c}\text { Well water + L-cysteine (250 } \\
\text { ppm) }+\mathbf{Z n}^{2+}(50 \text { ppm })\end{array}$ & -523 & 0.1863 & 0.2075 & $1.168 \times 10^{-6}$ & 36560.5 \\
\hline
\end{tabular}




\section{Analysis of AC impedance spectra}

AC impedance spectra (electro chemical impedance spectra) have been used to confirm the formation of a protective film on the metal surface [45-47]. If a protective film is formed on the metal surface, charge transfer resistance $\left(R_{t}\right)$ increases, double layer capacitance value $\left(\mathrm{C}_{\mathrm{dl}}\right)$ decreases and impedance log (z/ohm) value increases. The phase angle also increases. The AC impedance spectra of carbon steel immersed in well water, in the presence and absence of inhibitors (L-cysteine- $\mathrm{Zn}^{2+}$ ), are shown in Figs. 3 (a, b) (Nyquist plots), Figs. 4 (a,b) and Figs. 5 (a, b) (Bode plots). The AC impedance parameters, namely charge transfer resistance $\left(\mathrm{R}_{\mathrm{t}}\right)$ and double layer capacitance $\left(\mathrm{C}_{\mathrm{dl}}\right)$ derived from Nyquist plots are given in Table 7. The impedance $\log (\mathrm{z} / \mathrm{ohm})$ values derived from Bode plots are also given in Table 7.

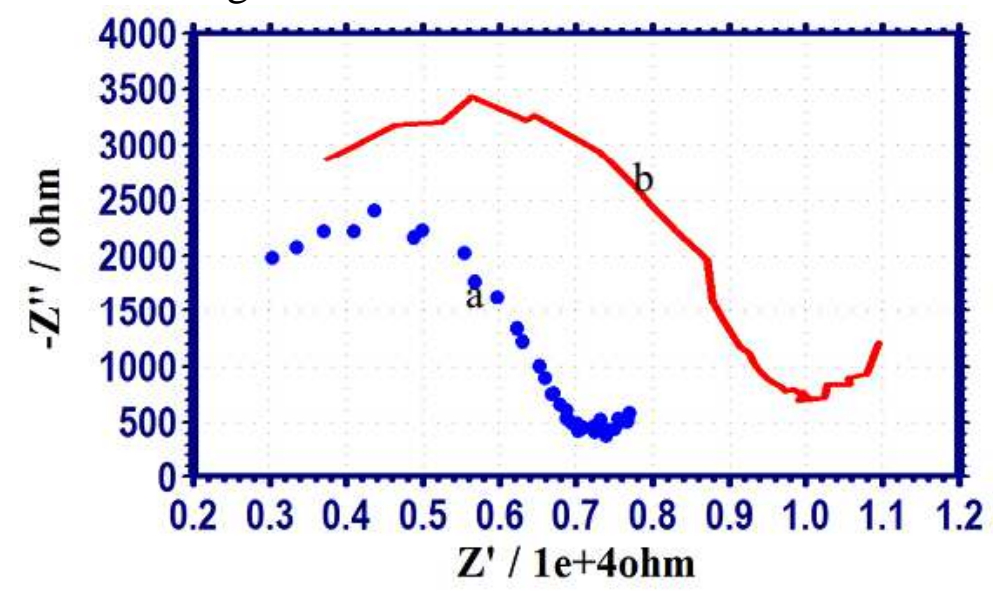

Figure 3. AC impedance spectra of carbon steel immersed in various test solutions. (Nyquist plots) $\mathrm{pH}=3$. a) Well water. b) Well water $+\mathrm{L}$-cysteine $(250 \mathrm{ppm})+\mathrm{Zn}^{2+}(50$ ppm).
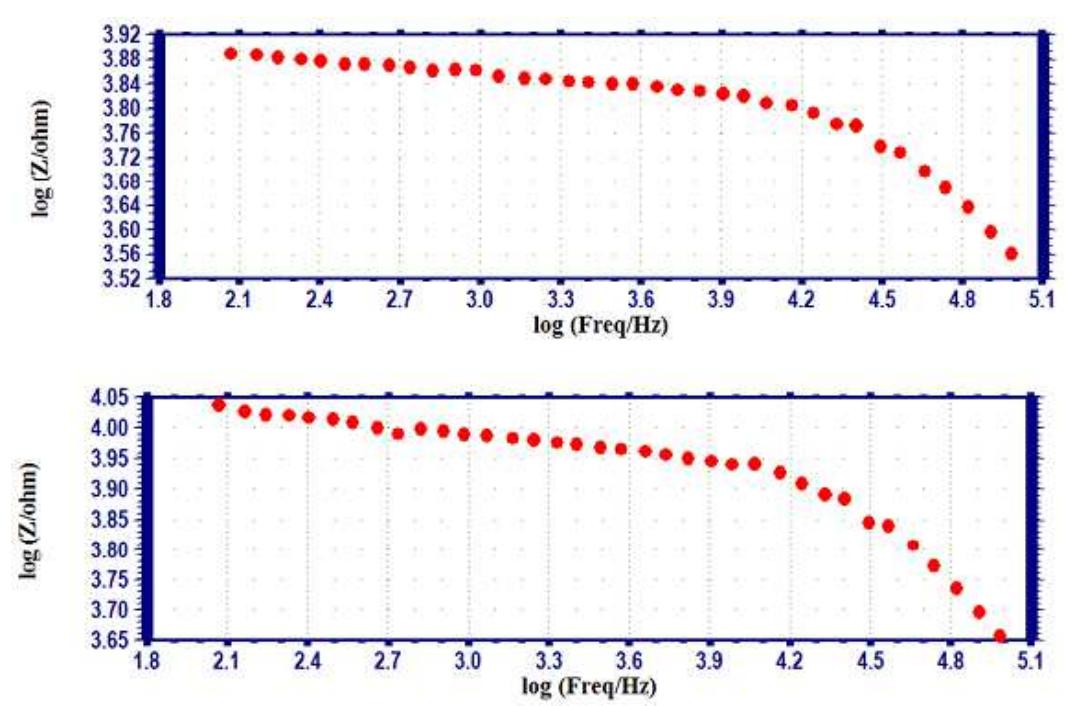

Figure 4. AC impedance spectra of carbon steel immersed in various test solutions. (Impedance - Bode plots) $\mathrm{pH}=3$. a) Well water. b) Well water + L-cysteine (250 ppm) $+\mathrm{Zn}^{2+}(50 \mathrm{ppm})$.

It is observed that, when the inhibitors [L-cysteine $\left.(250 \mathrm{ppm})+\mathrm{Zn}^{2+}(50 \mathrm{ppm})\right]$ are added, the charge transfer resistance $\left(R_{t}\right)$ increases from $4737 \mathrm{ohm} \mathrm{cm}^{2}$ to 
$7336 \mathrm{ohm} \mathrm{cm}^{2}$. The $\mathrm{C}_{\mathrm{dl}}$ value decreases from $1.056 \times 10^{-9} \mathrm{~F} / \mathrm{cm}^{2}$ to $0.6816 \times 10^{-9}$ $\mathrm{F} / \mathrm{cm}^{2}$. The impedance value $[\log (\mathrm{z} / \mathrm{ohm})]$ increases from 3.8862 to 4.043 . The phase angle increases from $34.00^{\circ}$ to $39.00^{\circ}$. These results lead to the conclusion that a protective film is formed on the metal surface.
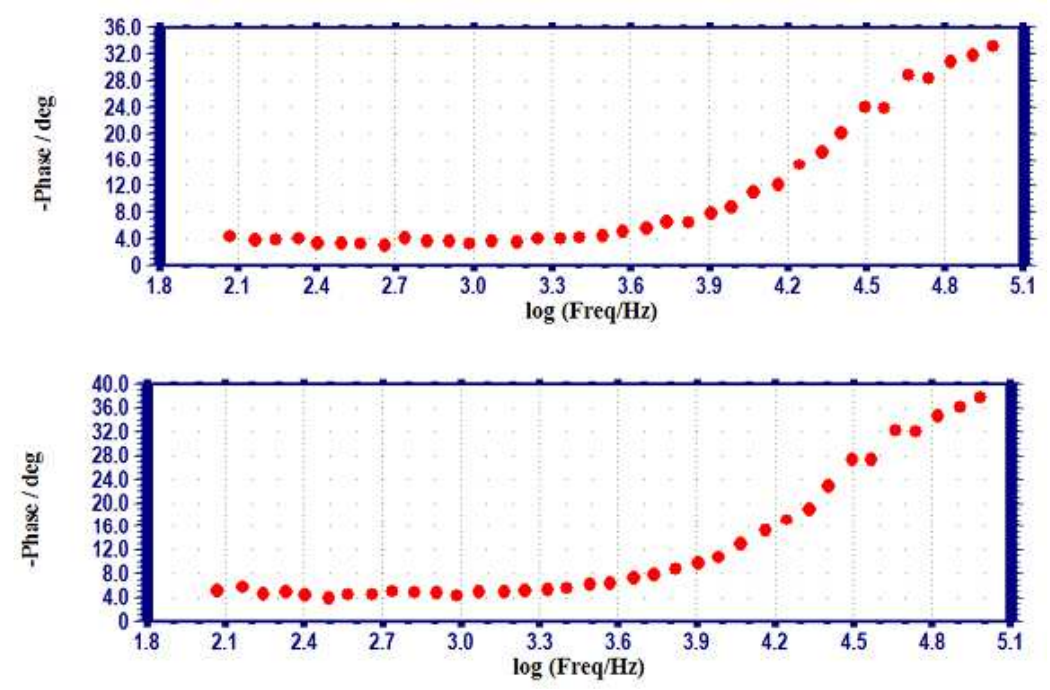

Figure 5. AC impedance spectra of carbon steel immersed in various test solutions. (Phase - Bode plots) $\mathrm{pH}=3$. a) Well water. b) Well water + L-cysteine $(250 \mathrm{ppm})+$ $\mathrm{Zn}^{2+}(50 \mathrm{ppm})$.

\section{Analysis of FTIR spectra}

FTIR spectra have been used to analyze the protective film formed on the metal surface [48-56]. The FTIR spectrum $(\mathrm{KBr})$ of pure L-cysteine is shown in Fig. 6 (a). The $-\mathrm{C}=\mathrm{O}$ stretching frequency of carboxyl group appears at $1640 \mathrm{~cm}^{-1}$. The $-\mathrm{CN}$ stretching frequency appears at $1131.7 \mathrm{~cm}^{-1}$. The $-\mathrm{NH}$ stretching frequency of the amine group appears at $2972.6 \mathrm{~cm}^{-1}$ [51-53]. The -CS stretching frequency appears at $634.8 \mathrm{~cm}^{-1}$.

Table 7. Corrosion parameters of carbon steel immersed in well water, in the absence and presence of an inhibitor system, obtained from AC impedance spectra $(\mathrm{pH}=3)$.

\begin{tabular}{|c|c|c|c|}
\hline \multirow{2}{*}{ System } & \multicolumn{2}{|c|}{ Nyquist plot } & Bode plot \\
\cline { 2 - 4 } & $\mathbf{R}$, $\mathbf{~ o h m ~} \mathbf{c m}^{\mathbf{2}}$ & $\mathbf{C}_{\mathbf{d I}}, \mathbf{F} / \mathbf{c m}^{\mathbf{2}}$ & Impedance value, $\mathbf{L o g}(\mathbf{z} / \mathbf{o h m})$ \\
\hline Well water & 4737 & $1.056 \times 10^{-9}$ & 3.886 \\
\hline $\begin{array}{c}\text { Well water + L-cysteine } \\
(\mathbf{2 5 0} \mathbf{~ p p m})+\mathbf{Z n}^{\mathbf{2 +}}(\mathbf{5 0} \mathbf{~ p p m})\end{array}$ & 7336 & $0.6816 \times 10^{-9}$ & 4.043 \\
\hline
\end{tabular}

The FTIR spectrum of the film formed on the metal surface, after immersion in well water containing $250 \mathrm{ppm}$ of L-cysteine and $50 \mathrm{ppm} \mathrm{Zn}^{2+}$, is shown in Fig. 6(b).

The $-\mathrm{C}=\mathrm{O}$ stretching frequency has shifted from $1640 \mathrm{~cm}^{-1}$ to $1636.4 \mathrm{~cm}^{-1}$. The $-\mathrm{CN}$ stretching frequency has shifted from 1131.7 to $1021.0 \mathrm{~cm}^{-1}$. The $-\mathrm{NH}$ stretching frequency has shifted from 2972.6 to $2920.1 \mathrm{~cm}^{-1}$. The $-\mathrm{CS}$ stretching frequency has shifted from $634.8 \mathrm{~cm}^{-1}$ to $603.6 \mathrm{~cm}^{-1}$. This observation suggests that L-cysteine has coordinated with $\mathrm{Fe}^{2+}$, through the oxygen atom of the 
carboxyl group and nitrogen atom of the amine group, resulting in the formation of the $\mathrm{Fe}^{2+}$-L-cysteine complex on the anodic sites of the metal surface. The peak at $443.9 \mathrm{~cm}^{-1}$ corresponds to $\mathrm{Zn}-\mathrm{O}$ stretching. The peak at $3399.8 \mathrm{~cm}^{-1}$ is due to $\mathrm{OH}$ stretching. This confirms that $\mathrm{Zn}(\mathrm{OH})_{2}$ is formed on the cathodic sites of the metal surface $[45,54-56]$. Thus, the FTIR spectral study leads to the conclusion that the protective film consists of $\mathrm{Fe}^{2+}$-L-cysteine complex and $\mathrm{Zn}(\mathrm{OH})_{2}$. This accounts for the synergistic effect between the amino acid and $\mathrm{Zn}^{2+}$.

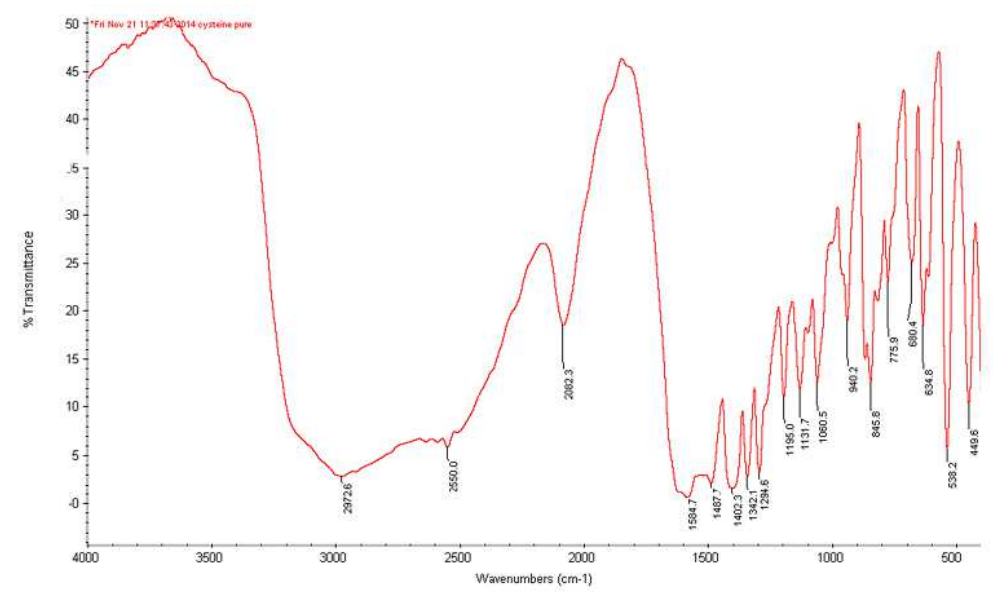

Figure 6a). FTIR spectrum of pure L-cysteine.

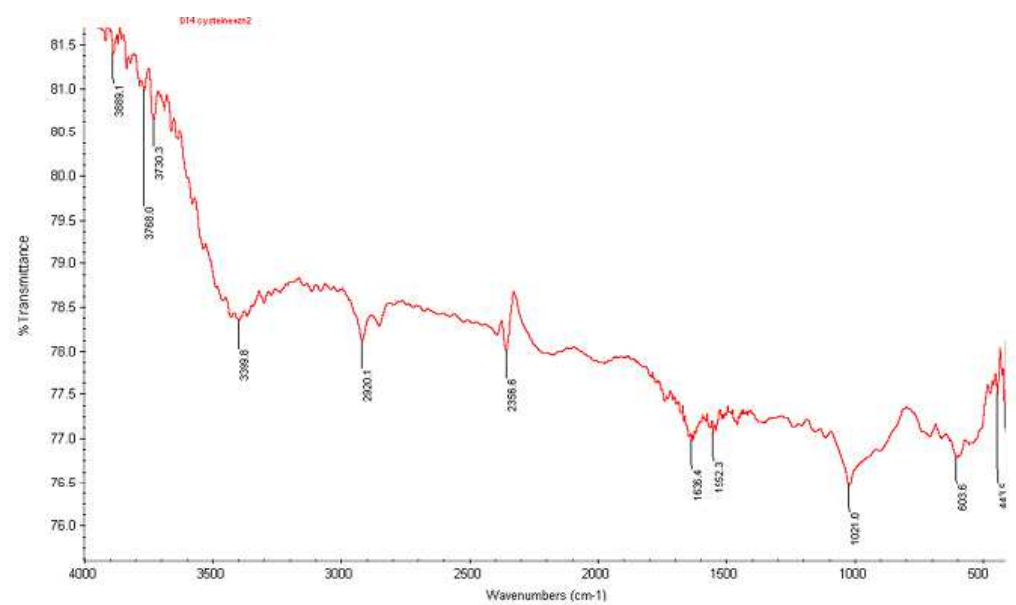

Figure 6b). FTIR spectrum of the film formed on the metal surface after immersion in a solution containing L-cysteine $-\mathrm{Zn}^{2+}$.

\section{Mechanism of corrosion inhibition}

The results of the weight-loss study show that the formulation consisting of 250 ppm L-Cys and $50 \mathrm{ppm}$ of $\mathrm{Zn}^{2+}$ has $99 \%$ IE in controlling corrosion of carbon steel in well water. A synergistic effect exists between $\mathrm{Zn}^{2+}$ and L-Cys. Polarization study reveals that this formulation functions as a mixed type of inhibitor. AC impedance spectra reveal that a protective film is formed on the metal surface. FTIR spectra reveal that the protective film consists of $\mathrm{Fe}^{2+}$-L-Cys complex and $\mathrm{Zn}(\mathrm{OH})_{2}$. In order to explain these facts, the following mechanism of corrosion inhibition is proposed [57-68].

When the solution containing well water, $50 \mathrm{ppm} \mathrm{Zn}^{2+}$ and $250 \mathrm{ppm}$ of L-Cys is prepared, there is formation of $\mathrm{Zn}^{2+}$-L-Cys complex in the solution. 
When carbon steel is immersed in this solution, the $\mathrm{Zn}^{2+}-\mathrm{L}-\mathrm{Cys}$ complex diffuses from the bulk of the solution towards the metal surface.

$\mathrm{Zn}^{2+}$-L-Cys complex diffuses from the bulk solution to the surface of the metal and is converted into a $\mathrm{Fe}^{2+}-\mathrm{L}-\mathrm{Cys}$ complex, which is more stable than $\mathrm{Zn}^{2+}-\mathrm{L}-$ Cys [50].

On the metal surface $\mathrm{Zn}^{2+}$ - L-Cys complex is converted into $\mathrm{Fe}^{2+}-\mathrm{L}-\mathrm{Cys}$ on the anodic sites. $\mathrm{Zn}^{2+}$ is released.

$$
\mathrm{Zn}^{2+}-\mathrm{L}-\mathrm{Cys}+\mathrm{Fe}^{2+} \rightarrow \mathrm{Fe}^{2+}-\mathrm{L}-\mathrm{Cys}+\mathrm{Zn}^{2+}
$$

The released $\mathrm{Zn}^{2+}$ combines with $\mathrm{OH}^{-}$to form $\mathrm{Zn}(\mathrm{OH})_{2}$ on the cathodic sites [50].

$$
\mathrm{Zn}^{2+}+2 \mathrm{OH}^{-} \rightarrow \mathrm{Zn}(\mathrm{OH})_{2} \downarrow
$$

Thus, the protective film consists of the $\mathrm{Fe}^{2+}-\mathrm{L}-\mathrm{Cys}$ complex and $\mathrm{Zn}(\mathrm{OH})_{2}$ $[69,70]$.

\section{Conclusions}

1. The polarization study reveals that this formulation functions as a mixed type inhibitor system.

2. AC impedance spectra reveal that a protective film is formed on the metal surface.

3. The FTIR spectra study leads to the conclusion that the $\mathrm{Fe}^{2+}-\mathrm{L}-\mathrm{Cys}$ complex formed on anodic sites of the metal surface controlled the anodic reaction, and that $\mathrm{Zn}(\mathrm{OH})_{2}$ formed on the cathodic sites of the metal surface controlled the cathodic reaction.

\section{References}

1. Baral A, Engelken RD. Environ Sci Policy. 2002;5:12.

2. Gaidis JM. Cement Concrete Comp. 2004;26:181.

3. Stupnisek-Lisac E, Bozic AL, Cafuk I. Corrosion. 1998;54:713.

4. El-Etre AY. Corrosion Sci. 2003;45:2485.

5. El-Etre AY. Corrosion Sci. 1998;45:1842.

6. Ashassi-Sorkhabi H, Majidi MR, Seyyedi K. Appl Surf Sci. 2004;225:176.

7. Ghasemi Z, Tizpar A. Appl Surf Sci. 2006;252:3667.

8. Zhang DQ, Gao LX, Zhou GD. J Appl Electrochem. 2005;35:1081.

9. Olivares O, Likhanova NV, Gomez BN, et al. Appl Surf Sci. 2006;252:2894.

10. Badawy WA, Ismail KM, Fathi AM. Electrochim Acta. 2006;51:4182.

11. Ismail KM. Electrochim Acta. 2007;52:7811.

12. Ashassi-Sorkhabi H, Ghasemi Z, Seifzadeh D. Appl Surf Sci. 2005;249:408.

13. Oguzie EE, Li Y, Wang FH. J Colloid Interf Sci. 2007;310:90.

14. Onal AA. Bull Electrochem. 1995;1:513.

15. Gomma G. Bull Electrochem. 1998;12:456. 
16. Kalota D, Silverman D. Corrosion Sci. 1994;50:138.

17. Madkour L, Ghoneion M. Bull Electrochem. 1997;13:1.

18. Morad M, Hermas A, Aal M. J Chem Technol Biotechnol. 2002;77:486.

19. El-Shafei AA, Moussa MNH, El-Far AA. J Appl Electrochem. 1997;27:1075.

20. Fouda A, El-Semongy M. J Indian Chem Soc. 1982;59:89.

21. Aksut A, Bilgic S. Corros Sci. 1992;33:372.

22. Gomma G, Wahdan H. Mater Chem Phys. 1994;39:142.

23. Moretti G, Guidu F. Corrosion Sci. 2002;44:1995.

24. Rylkina M, Chikanova A, Trubacheva L, et al. Protect Metals. 1999;35:1987.

25. Baba H, Kodama T. Corrosion Sci. 1980;41:1995.

26. Ita BI. Bull Electrochem. 2005;21:319.

27. Canul MAP, Bartolo-Perez P. Surf Coat Technol. 2004;184:184.

28. Canul MAP, Echeverria M. Corrosion Eng Sci Technol. 2003;38:135.

29. Rajappa SK, Ventatesha TV. Turk J Chem. 2003;27:189.

30. Chi-Canul LP. Corrosion. 1999;55:948.

31. Akiyama A, Nobe N. J Electrochem Soc. 1970;117:999.

32. Wranglen G. An introduction to corrosion and protection of metals. New York: Chapman \& Hall; 1985.

33. Gomma GK. Mater Chem Phys. 1998;55:241.

34. Aramaki K, Hackermann N. J. Electrochem. Soc. 1969;116:568.

35. Quraishi MA, Rawat J, Ajmal M. Corrosion. 1999;55:919.

36. Kanimozhi SA, Rejendran S. Int J Electrochem Soc. 2009;4:353.

37. Gopi D, Manimozhi S, Govindaraju KM, et al. J Appl Electrochem. 2007;37:439.

38. Rajendran S, Raj AJA, Joice MJ, et al. Corrosion Rev. 2004;22:233.

39. Roque JM, Padiyan T, Cruz J, et al. Corrosion Sci. 2008;50:614.

40. Benali O, Larabi L, Traisnel M, et al. Appl Surf Sci. 2007;253:6130.

41. Amar H, Braisaz T, Villemin D, et al. Mater Chem Phys. 2008;110:1.

42. Selvi JA, Rajendran S, Sri VG, et al. Port Electrochim Acta. 2009;27:1.

43. Rajendran S, Paulraj J, Rengan P. et al. J Dent Oral Hyg. 2009;1:1.

44. Kalman E, Felhosi I, Karman FH, et al. Corrosion and environmental degradation. In: Schutze M, editor. Weinheim: Wiky-VCh; 2000.

45. Zhang S, Tao Z, Li W, et al. Appl Surf Sci. 2009;255:6757.

46. Heakal FT, Fouda AS, Radwan MS. Mater Chem Phys. 2011;125:26.

47. Rajendran S, Devi MK, Regis APP, et al. Zastita Materijala. 2009;50:131.

48. Amar H, Braisaz T, Villemin D, et al. Mater Chem Phys. 2008;110:1-6.

49. Kalaivani R, Narayanasamy B, Selvi JA, et al. Port Electrochim Acta. 2009;27:177.

50. Sathiyabama J, Rajendran S, Selvi AA, et al. Open Corrosion J. 2009;2:76.

51. Silverstein RM, Bassler GC, Moril T. Spectrometric identification of organic compound. New York: John Wiley and Sons; 1981.

52. Cross AD. Introduction to practical infrared spectroscopy. London: Butterworths, Scientific Publication; 1990. 
53. Nakamoto K. Infrared and Raman spectra of inorganic coordination compound. New York: Wiley Interscience; 1986.

54. Rajendran S, Apparao BV, Palaniswamy N. Bull Electrochem. 1996;12:15.

55. Sekine I, Hirakawa V. Corrosion. 1986;42.

56. Rajendran S, Apparao BV, Palaniswamy N. Proceedings $8^{\text {th }}$ Eur Symp Corros Inhibitors. Ferrara; 1995. P. 465.

57. Epshiba R, Regis APP, Rajendran S. Int J Nano Corrosion Sci Eng. 2014;1:1-11.

58. Kavitha N, Manjula P. Int J Nano Corrosion Sci Eng. 2014;1:31-38.

59. Nagalakshmi R, Nagarajan L, Rathish RJ, et al. Int J Nano Corrosion Sci Eng. 2014;1:39-49.

60. Thangakani JA, Rajendran S, Sathiabama J, et al. Int J Nano Corrosion Sci Eng. 2014;1:50-62.

61. Nithya A, Shanthy P, Vijaya N, et al. Int J Nano Corrosion Sci Eng. 2015;2:1-11.

62. Gowrani T, Manjula P, Baby N, et al. Int J Nano Corrosion Sci Eng. 2015;2:12-21.

63. Johar NK, Bhrara K, Epshiba R, et al. Int J Nano Corrosion Sci Eng. 2015;2:22-31.

64. Mary ACC, Rajendran S, Al-Hashem H, et al. Int J Nano Corrosion Sci Eng. 2015;2:42-50.

65. Thangakani JA, Rajendran S, Sathiabama J, et al. Int J Nano Corrosion Sci Eng. 2015;2:18-25.

66. Raja AS, Rajendran S, Sathiyabama J, et al. Int J Nano Corrosion Sci Eng. 2015;2:26-40.

67. Shanthy P, Rajendran S, Joany RM, et al. Int J Nano Corrosion Sci Eng. 2015;2:41-51.

68. Raja AS, Rajendran S, Sathiyabama J, et al. Int J Nano Corrosion Sci Eng. 2015;2:52-60.

69. Ruba HFG, Noreen AA, Sahayaraj JW, et al. Indian J Chem Technol. 2005;12:472.

70. Selvarani FR, Santhamadharasi S, Sahayaraj JW, et al. Indian J Chem Technol. 2005;12:472. 